\title{
Steroidal and Non-Steroidal Cyclooxygenase-2 Inhibitor Anti-Inflammatory Drugs as Pre-Emptive Medication in Patients Undergoing Periodontal Surgery
}

\author{
Maria Fernanda Santos PERES \\ Fernanda Vieira RIBEIRO \\ Karina Gonzalez Silvério RUIZ \\ Francisco Humberto NOCITI-JR \\ Enilson Antônio SALLUM \\ Márcio Zaffalon CASATI
}

\begin{abstract}
Department of Prosthodontics and Periodontics, Piracicaba Dental School, UNICAMP - University of Campinas, Piracicaba, SP, Brazil
\end{abstract}

\begin{abstract}
The aim of the present study was to compare the pre-emptive use of a cyclooxygenase-2 (COX-2) inhibitor with a well established steroidal anti-inflammatory drug for pain and edema relief following periodontal surgery for crown lengthening. Thirty patients requiring periodontal surgery were randomly assigned to receive one of the following medications: selective COX-2 inhibitor or steroidal antiinflammatory drug, $60 \mathrm{~min}$ before the surgical procedure. To examine patient anxiety, a Corah's dental anxiety scale was applied before surgery. Using a visual analog scale, the extent of pain/discomfort during the trans-operative period and immediately after the surgery was measured. Additionally, intensity of pain/discomfort and edema were examined 4, 8, 12 and 24 h postoperatively. With regard to anxiety, no statistical differences between the groups were observed ( $p>0.05$ ). With respect to the extent of pain/discomfort during the trans-operative, immediate and late postoperative period, data demonstrated no significant differences ( $p>0.05)$ between the COX-2 inhibitor and steroidal groups. With regard to edema, intragroup analysis did not reveal any statistically significant difference ( $p>0.05$ ) during the $24 \mathrm{~h}$ following surgery in either group. In conclusion, both anti-inflammatory drugs presented a similar potential for pain and edema relief following periodontal surgery.
\end{abstract}

Key Words: anti-inflammatory, pre-emptive drugs, periodontal surgery, crown lengthening.

\section{INTRODUCTION}

One of the most common reasons for periodontal surgery is for crown lengthening purposes (1). Crown lengthening procedures may involve the surgical removal of hard and soft periodontal tissues to gain supracrestal tooth length, allowing for longer clinical crowns and reestablishment of the biological width $(1,2)$. Postoperative pain, discomfort and edema after surgical procedures and specifically periodontal surgery are common occurrences, especially during the first 24 $\mathrm{h}$ following surgery and may be considered an example of acute dental pain of mild to moderate severity (3-5).
In this context, the use of pre-emptive medication, aiming to prevent postsurgical pain and discomfort is of great importance. Some trials suggest that preoperative administration of different anti-inflammatory medications, both non-steroidal anti-inflammatory drugs (NSAIDs) and steroidal anti-inflammatory drugs (SAIDs), may reduce postoperative pain intensity and the need for supplementary analgesics (5-7). Most dental practitioners tend to use steroidal anti-inflammatory drugs, i.e. dexamethasone, as pre-emptive medications (8). Their mechanism of action includes the inhibition of the A2 phospholipase enzyme, which reduces the release of arachidonic acid in the cells of the inflamed

Correspondence: Prof. Dr. Márcio Zaffalon Casati, Departamento de Prótese e Periodontia, Faculdade de Odontologia de Piracicaba, UNICAMP, Avenida Limeira, 901, Areião, 13414-903 Piracicaba, SP, Brasil. Tel: +55-19-2106-5301. e-mail: casati@fop.unicamp.br 
focus. This will decrease the synthesis of prostaglandins and leukotrienes, therefore reducing the accumulation of neutrophils and justifying, at least in part, the power of steroidal anti-inflammatory drugs (8).

Some studies have also shown positive results with the use of pre-emptive NSAIDs for the management of postoperative pain (9). NSAIDs inhibit the cyclooxygenase (COX) enzyme cascade, producing effects on the arachidonic acid metabolism and on the synthesis of prostaglandins (10). COX has several forms and the most investigated are COX-1 and COX-2. COX-1, a constitutive form expressed in many tissues, produces prostaglandins for homeostasis within the body, its main functions being to protect the gastrointestinal tract, increase renal function, influence the central nervous system and increase vascular permeability. COX-2, an inducible form, produces prostaglandins that mediate the inflammatory response and pain-signaling transmissions (7). Conventional non-selective NSAIDs inhibit COX-1 as well as COX-2, which can provoke adverse side effects, such as stomach and renal toxicity (10). For this reason, selective COX-2 inhibitors have emerged with the objective of reducing these side effects.

The selective COX-2 inhibitor used in the present trial has analgesic and anti-inflammatory activity, may be rapidly absorbed, presenting good oral bioavailability and differs from other inhibitors in that it is acidic, which promotes its preferential distribution into inflamed tissue $(4,10,11)$.

Although some studies have demonstrated a better effect in the control of pain and edema when using steroid versus non-steroidal anti-inflammatory drugs (12), there is no information comparing the use of a steroidal with a non-steroidal COX-2 inhibitor anti-inflammatory drug as pre-emptive medication. Moreover, there is lack of information concerning their use as pre-emptive medications in periodontal crown lengthening surgeries. As such, the purpose of the present study was to compare the pre-emptive effect of a non-steroidal COX-2 inhibitor with a SAID, a more traditional and commonly used pre-emptive medication, for periodontal surgery of crown lengthening.

\section{MATERIAL AND METHODS}

\section{Study Design}

This study was designed as a double-blind randomized parallel study to compare two different pre- emptive medications in patients requiring periodontal surgery for crown lengthening in maxillary and mandibular posterior sextants (pre molars and molars). The study design was approved by the Ethics Committee of the University of Campinas (Protocol\#016/2008). All patients received a detailed description of the proposed treatment and gave their written informed consent.

\section{Population Screening}

Thirty patients, selected from those referred to the Graduate Clinic of the Piracicaba Dental School, UNICAMP, Brazil were subjected to complete periodontal examination, radiographic examination and detailed clinical interview.

The study inclusion criteria were: at least one tooth that needed to be submitted to periodontal surgery for crown lengthening, confirmed by clinical and radiographic evidence and full-mouth plaque score (FMPS) and full-mouth bleeding score (FMBS) $<20 \%$. Patients who were pregnant or lactating, had any conditions that contra-indicated the use of the medications used in the study or received medications able to interfere in pain threshold, analgesics or antiinflammatory drugs in the previous two weeks, were excluded from the study.

All patients had an initial periodontal treatment performed by the same operator. This initial treatment consisted of supragingival calculus removal and prophylaxis, non-surgical scaling and root planning performed as required in areas presenting pocket probing depth (PPD) $>3 \mathrm{~mm}$ and bleeding on probing (BOP) in one debridement session and two motivation sessions with an interval of 15 days, during which oral hygiene instructions were given. The patients were maintained in periodontal supportive therapy. Afterwards, those who fulfilled the inclusion criteria were enrolled in the study.

\section{Pre-Surgical Procedures}

Prior to surgery, clinical measurements were evaluated by a calibrated examiner. All parameters were measured using a PCP-15 periodontal Probe (Hu Friedy do Brasil, Rio de Janeiro, RJ, Brazil). FMPS (13) and FMBS (14) were calculated after assessing dichotomously the presence of plaque or bleeding on probing from the bottom of the pocket with a manual probe and calculating the percentage of sites that revealed the presence of plaque or bleeding. Osseous probing 
was also carried out under local anesthesia to determine the distance from the alveolar bone crest to the cavity and to verify the need of ostectomy during the surgical procedure. Periapical radiographs (Ektaspeed; Kodak, São Paulo, SP, Brazil) were taken at baseline with the long cone paralleling technique using film-holders, to confirm the need of bone resection during the surgery. All radiographs were evaluated by the same examiner after intraexaminer calibration.

\section{Patient-Centered Outcomes}

Due to the fact that stress and dental anxiety vary among patients and may influence patient pain perception, Corah's dental anxiety scale (15) was applied at the beginning of the study, immediately before the surgical procedure.

To evaluate the patient's perception regarding the morbidity during the procedure and during the post-therapy period, patients received a questionnaire immediately after the surgery. Using a $100 \mathrm{~mm}$ horizontal visual analog scale (VAS), the intensity of discomfort/ pain experienced during the trans-operative period and immediately after the surgery (immediate postoperative period) was measured. The anchors for each end of the scales were designated as "none" and "extreme". Additionally, both intensity of pain/discomfort and perception of edema were measured during the late postoperative period - after 4, 8, 12 and $24 \mathrm{~h}$ following surgery - using VAS.

\section{Treatment}

All surgical procedures were performed by the same operator, who was different from the operator that performed the initial therapy. One hour before surgery, each patient was randomly assigned to receive one of the following pre-emptive medications: NSAID COX-2 inhibitor: single doses of $400 \mathrm{mg}$ Lumiracoxib (Prexige; Novartis, Taboão da Serra, SP, Brazil) or SAID: single doses of $4 \mathrm{mg}$ dexamethasone (Decadron; Aché, Guarulhos, SP, Brazil). The participants did not know which medication they were given and all medications were in powdered form by an independent person, who was not the person preparing the medication or recording the pain levels.

With regard to the surgical procedures, all patients were treated as follows: before surgery, intraoral antisepsis was performed with a $0.12 \%$ chlorhexidine rinse solution and extraoral antisepsis was carried out with iodine solution. Following local anesthesia (Lidocaine/epinephrine 1:100 000; DFL, Rio de Janeiro, RJ, Brazil), an internal bevel incision about 1 to $2 \mathrm{~mm}$ from the gingival margin was carried out, followed by an intrasulcular incision with a $15 \mathrm{C}$ blade (Swann-Morton, Sheffield, South Yorkshire, England). After that, the collar tissue was removed with Gracey curettes $(\mathrm{Hu}-$ Friedy, Chicago, IL, USA) and the total flap was reflected exposing the subjacent bone crest. Only the associated area was accessed and vertical-releasing incisions were not made, with the full-thickness flap being minimally elevated. Granulation tissues were carefully removed with curettes (Gracey; Hu-Friedy). Then, the distance from bone crest to cavity was measured and osteotomy was performed with burs (KG Sorensen, Barueri, SP, Brazil) under irrigation and periodontal files. After this, the flaps were positioned and sutured with a nylon 5-0 suture (Ethicon, São José dos Campos, SP, Brazil) to obtain primary closure of the inter-dental tissues. The chair time of each surgical procedure was registered, starting from the injection of local anesthesia and ending with completion of sutures, since this factor may influence the postoperative status. The number of teeth involved in the procedure was also recorded.

\section{Postoperative Care}

At the end of all procedures, patients received analgesic medication - five pills (Dypirone, $500 \mathrm{mg}$; EMS, São Bernardo do Campo, SP, Brazil) and were instructed to take the medication every $4 \mathrm{~h}$, but only if they experienced pain. Patients were also instructed to quantify analgesic medication taken. For biofilm control, all patients, independently of treatment received, were instructed to rinse with a $0.12 \%$ chlorhexidine solution twice a day during 7 days. The sutures of surgical group sites were removed at 7 days post-surgery.

\section{Randomization and Allocation Concealment}

The study employed a double-blind, randomized and parallel design. All patients included in the study were recruited before the beginning of the randomization to therapeutic approaches. The pre-emptive medication was determined for each patient immediately before the beginning of the procedure (steroidal or non-steroidal COX-2 inhibitor anti-inflammatory drug) by random sorting that was performed by a different operator 
from the one responsible for the surgical procedure and different from the examiner. The randomization code was not broken until all data were collected. Thus, the treatment group was not revealed to the clinical examiner or to the statistician.

\section{Statistical Analysis}

The statistical analysis tested the null hypothesis that the non-steroidal selective COX-2 inhibitor and the steroidal anti-inflammatory medications promote similar pre-emptive effects for the control of pain/ discomfort and edema after periodontal surgery for crown lengthening.

To test this hypothesis, the BioEstat 5.0 software was used. The analysis of the anxiety level was made using the Mann Whitney test. Student's t-test was used to compare the time required for the procedure and the number of analgesics taken in the postoperative period in each group. Since the pain scores did not show normal distribution and homogeneity of variances, the nonparametric Mann-Whitney test was used to determine the difference between the groups every $4 \mathrm{~h}$, during the first $12 \mathrm{~h}$ and after $24 \mathrm{~h}$ following surgeries. The Friedman non parametric test was used to compare pain/discomfort and edema at different periods in the same group. An experimental level of significance was determined at $5 \%$ for all statistical analyses $(\alpha=0.05)$.

\section{RESULTS}

\section{Subject Accountability}

Figure 1 presents the study flowchart. Thirty patients, presenting a total of 30 areas requiring surgical procedures for crown lengthening, were initially recruited at the beginning of the study. Two patients were lost later during follow-up for not presenting the VAS questionnaire in the postoperative recall. All other 28 subjects were included in the statistical analyses.

\section{Study Schedule}

Subject recruitment started in 10/2008 and was completed by the end of $01 / 2009$. The first procedure was carried out in 11/2008 and all the study evaluations were completed in $03 / 2009$. Data entry of all information and statistical analyses were performed by the end of 06/2009.

\section{Patients' Characteristics at Baseline}

Patients' characteristics at baseline were not significantly different between groups (Table 1), confirming the homogeneity between groups before the therapy.

\section{Surgical Chair Time, Number of Teeth Involved, Number of Analgesics Taken}

With regard to the chair time required for the procedure, number of teeth involved in the surgery and number of analgesics taken in the postoperative period, no statistically significant differences were observed between groups for all evaluated aspects $(p>0.05)$ (Table 2).

\section{Patient-Centered Outcomes}

Concerning the anxiety level, in both groups the majority of patients showed very low anxiety levels, 9 patients reported anxiety in the selective COX-2 inhibitor group and 7 in the SAID group. Although none of the patients in the SAID group demonstrated any extreme

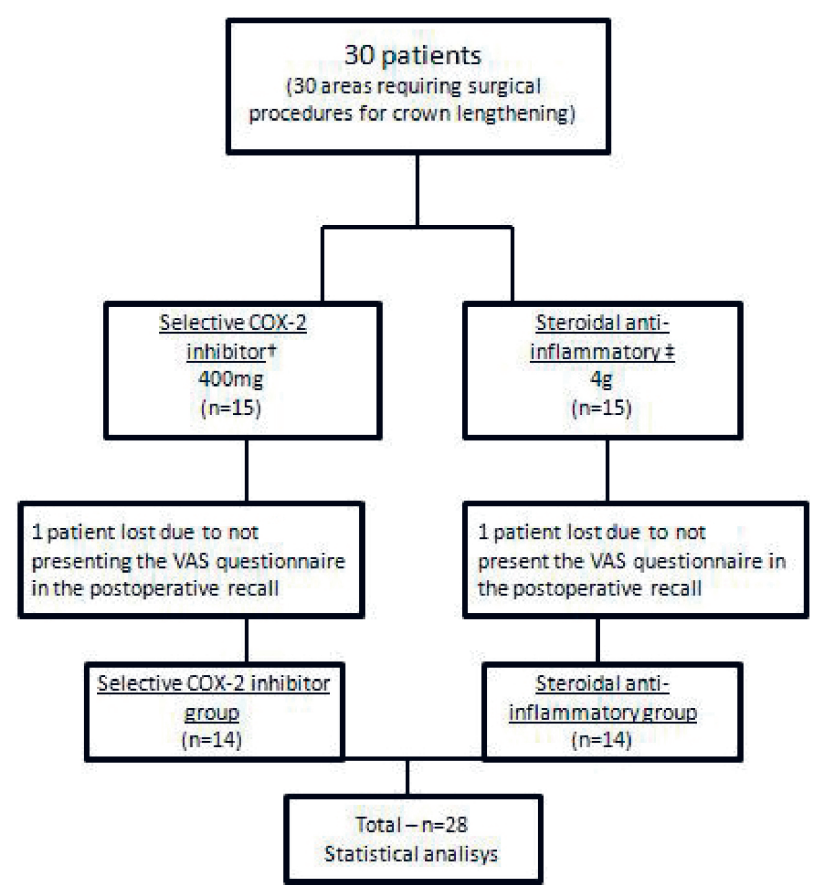

Figure 2. Each column represents the anxiety level in each group (Selective COX-2 inhibitor and SAID groups). No statistically significant differences in anxiety level between the groups (MannWhitney test; $\mathrm{p}>0.05$ ). 
anxiety level, statistical differences were not observed between groups ( $\mathrm{p}>0.05$ ) (Fig. 2).

Based on a horizontal visual analog scale, the intensity of discomfort/pain experienced during the surgical procedure and in the immediate postoperative period was found to be statistically similar between the COX-2 inhibitor and steroidal anti-inflammatory groups ( $>0.05$ ) (Table 3 ). With respect to the late postoperative period, although a trend towards lower values in the intensity of discomfort/pain and edema were found for the selective COX-2 inhibitor group, no significant differences were observed between the experimental groups at any of the time intervals following surgery $(p>0.05)$. Additionally, intragroup analysis revealed that the steroidal group did not present any statistically significant reduction in pain/discomfort among the time periods evaluated during the late postoperative phase ( $p>0.05$ ), whereas the COX-2 inhibitor group analysis demonstrated a significant reduction in pain/discomfort $24 \mathrm{~h}$ after surgery, as compared with the $4 \mathrm{~h}$ postoperative period $(p<0.05)($ Table 4$)$. With regard to the intensity of

Table 1. Patient characteristics at baseline.

\begin{tabular}{lcc}
\hline Patients & Selective COX-2 inhibitor & SAID \\
\hline Males & 4 & 2 \\
Females & 10 & 12 \\
Total & 14 & 14 \\
Age* & $34.43(8.37)$ & $33.00(10.91)$ \\
\hline
\end{tabular}

SAID: steroidal anti-inflammatory drug. Number of males and females and mean (S.D.) age (in years) in the groups. No significant differences were found between groups (Student's t-test), $\mathrm{p}>0.05$.

Table 2. Mean (S.D.) of surgical chair time, number of teeth involved in the procedure and number of analgesics taken after surgery, in each group.

\begin{tabular}{lcc}
\hline Variable & $\begin{array}{c}\text { Selective } \\
\text { COX-2 inhibitor }\end{array}$ & SAID \\
\hline $\begin{array}{l}\text { Surgery duration } \\
\text { (min) }\end{array}$ & $35.07(14.60)$ & $\begin{array}{c}42.00 \\
(18.05)\end{array}$ \\
Number of teeth & $1.07(0.27)$ & 1.64 \\
& & $(1.39)$ \\
Rescue pills taken & $1.07(1.00)$ & 1.14 \\
\hline
\end{tabular}

SAID: steroidal anti-inflammatory drug. No statistical differences were observed between groups (Student's t test), $\mathrm{p}>0.05$. edema, intragroup analysis did not reveal any statistically significant difference during the $24 \mathrm{~h}$ following surgery in both groups ( $>0.05$ ) (Table 5).

\section{DISCUSSION}

Periodontal surgery for crown lengthening is one of the most frequent procedures in periodontics and can lead to postoperative pain and discomfort $(1,2)$. This study compared the pre-emptive performance of a non-steroidal COX-2 inhibitor, with a steroidal antiinflammatory drug for periodontal surgery of crown lengthening. The results obtained in the present trial demonstrated that, regardless of the anti-inflammatory

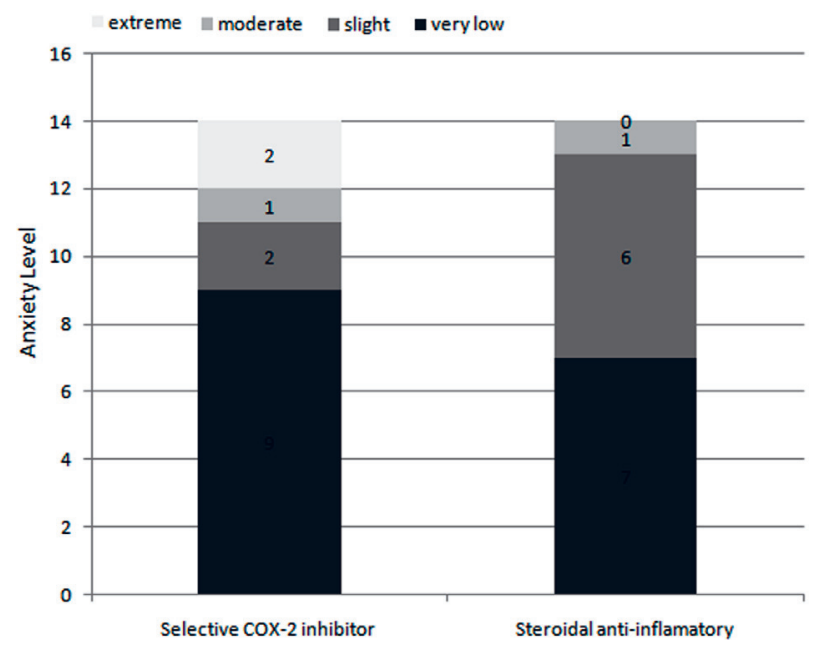

Figure 1. Flowchart of the study. †Lumiracoxib $400 \mathrm{mg}$ (Prexige; Novartis, Taboão da Serra, SP, Brazil). ‡Dexamethasone $4 \mathrm{mg}$ (Decadron; Aché, Guarulhos, SP, Brazil)

Table 3. Mean ( \pm SD) of discomfort/pain intensity during the surgery and in the immediate postoperative period.

\begin{tabular}{|c|c|c|}
\hline Time points & $\begin{array}{c}\text { Selective } \\
\text { COX-2 inhibitor }\end{array}$ & SAID \\
\hline Trans-operative & $9.06(10.30) \mathrm{Aa}$ & $\begin{array}{c}22.27(29.21) \\
\mathrm{Aa}\end{array}$ \\
\hline $\begin{array}{l}\text { Immediate } \\
\text { postoperative }\end{array}$ & $11.25(11.25) \mathrm{Aa}$ & $\begin{array}{c}28.34(26.78) \\
\text { Aa }\end{array}$ \\
\hline
\end{tabular}

SAID: steroidal anti-inflammatory drug. Means followed by different uppercase letters in rows represent significant inter-group differences by Mann Whitney test, $\mathrm{p}<0.05$. Means followed by different lowercase letters in columns represent significant intragroup differences by Wilcoxon, $\mathrm{p}<0.05$. 
type, both the COX-2 inhibitor and steroidal drugs presented a promising final outcome in the control of inflammatory signs and symptoms during the postoperative period.

In the present study, it was observed that the pain/ discomfort scores recorded during the trans-operative, immediate and late postoperative periods were not significantly different between the two groups, although a trend towards lower values was observed for the selective COX-2 inhibitor group.

In both groups, low pain scores were recorded during the entire evaluation period, immediately after surgery and $4 \mathrm{~h}$ postoperatively; patient perception was slightly higher than during the following periods when pain/discomfort intensity remained at the lowest levels, confirming the effectiveness of both anti-inflammatory drugs. After oral surgical procedures, a range of inflammatory mediators, such as prostaglandins, are synthesized rapidly after tissue injury and appear in significant concentrations $1 \mathrm{~h}$ after trauma, which can be associated with decreased patient well-being or pain/ discomfort after the procedure (16). Thus, pre-emptive anti-inflammatory drugs may prevent hyperalgesia, reducing postoperative pain and discomfort and the consumption of rescue analgesics. Although some studies have failed to demonstrate the superiority of preemptive medications (17), waiting for pain initiation after surgery to medicate can produce unnecessary discomfort and may reduce the efficacy of any posterior treatment (18). It should be mentioned that although several trials

Table 4. Mean (S.D.) of discomfort/pain intensity during the late postoperative period.

\begin{tabular}{lcc}
\hline Time point & $\begin{array}{c}\text { Selective } \\
\text { COX-2 inhibitor }\end{array}$ & SAID \\
\hline $4 \mathrm{~h}$ & $13.58(15.40) \mathrm{Aa}$ & $25.19(28.86) \mathrm{Aa}$ \\
$8 \mathrm{~h}$ & $8.82(11.20) \mathrm{Aab}$ & $18.89(21.84) \mathrm{Aa}$ \\
$12 \mathrm{~h}$ & $6.40(7.56) \mathrm{Aab}$ & $14.90(22.96) \mathrm{Aa}$ \\
$24 \mathrm{~h}$ & $4.79(6.02) \mathrm{Ab}$ & $11.80(20.57) \mathrm{Aa}$ \\
\hline
\end{tabular}

SAID: Steroidal anti-inflammatory drugs. Means followed by different uppercase letters in rows represent significant inter-group differences by the Mann Whitney test, $\mathrm{p}<0.05$. Means followed by different lowercase letters in columns represent significant intra-group differences by the Friedman test, $\mathrm{p}<0.05$. have assessed postoperative signs and symptoms only by the number of analgesics taken after surgery (20), this study chose instead to use also the pain/discomfort measured on a VAS to improve the analysis, similarly to the methodology described by a previous study (21).

Patient perception of pain and discomfort is highly subjective and varies considerably among individuals (20), according to the nature, duration, and extent of the surgery and depending on psychological aspects (e.g., stress and anxiety) (22). An important aspect of the present study is associated with the caution used to adequately evaluate the anxiety level before surgery and monitor the chair time required for the procedure, number of teeth involved in the surgery and number of analgesics taken in the postoperative period. For all these evaluated aspects, no differences were observed between the COX-2 inhibitor and steroidal groups, confirming the homogeneity of experimental groups and supporting the outcomes obtained in the study.

The present study focused on the first 24 postoperative hours because this peak pain period is the most representative part of the pain model and extension of the study beyond $24 \mathrm{~h}$ was considered unnecessary, according to previous investigations (23). In this study, intragroup analysis revealed that the SAID group did not present any reduction in pain/discomfort among the time points evaluated during the first 24 postoperative hours, whereas the COX-2 inhibitor intragroup analysis demonstrated a significant reduction in pain/discomfort $24 \mathrm{~h}$ after surgery, as compared with the $4 \mathrm{~h}$ postoperative

Table 5. Means (S.D.) of edema intensity during the late postoperative period.

\begin{tabular}{lcc}
\hline Time point & $\begin{array}{c}\text { Selective } \\
\text { COX-2 inhibitor }\end{array}$ & SAID \\
\hline $4 \mathrm{~h}$ & $4.96(7.26) \mathrm{Aa}$ & $8.91(13.62) \mathrm{Aa}$ \\
$8 \mathrm{~h}$ & $3.80(7.44) \mathrm{Aa}$ & $6.92(7.14) \mathrm{Aa}$ \\
$12 \mathrm{~h}$ & $4.19(9.71) \mathrm{Aa}$ & $5.48(5.94) \mathrm{Aa}$ \\
$24 \mathrm{~h}$ & $3.14(7.54) \mathrm{Aa}$ & $5.54(11.63) \mathrm{Aa}$ \\
\hline
\end{tabular}

SAID: Steroidal anti-inflammatory drug. Means followed by different capital letters in a line represent significant inter-group differences by the Mann Whitney test, $\mathrm{p}<0.05$. Means followed by different non-capital letters in the column represent significant intra-group differences by the Friedman test, $\mathrm{p}<0.05$. 
period. This finding may suggest an advantage in using a non-steroidal COX-2 inhibitor as pre-emptive medication for periodontal surgery of crown lengthening.

While the cardiovascular and hepatic safety of the COX-2 selective inhibitor used in the present trial has been discussed in cases where this medication was prescribed for chronic use, cardiovascular safety and hepatic tolerability with this COX-2 inhibitor has been demonstrated in patients with acute pain using a single dose and it has also been demonstrated that rates of adverse cardiovascular events (myocardial infarction, stroke and cardiovascular death) were similar with the COX-2 selective inhibitor used in the present study, compared with ibuprofen and naproxen $(23,24)$.

Although the crown lengthening surgeries performed in the present trial caused low pain/ discomfort and edema, it is reasonable to infer that more invasive periodontal surgeries, such as such as mucogingival surgery, osseous resective surgery, osseous reconstruction and implant placement may lead to a greater inflammatory response. Thus, the results of this investigation may not be applied to these types of surgeries. Further investigations including the enrollment of patients demanding periodontal surgical procedures expected to result in a higher degree of postoperative pain should be carried out to clearly indicate the potential of these anti-inflammatory drugs in these cases.

Additionally, the intensity of edema experienced during the late postoperative period was similar between the COX-2 inhibitor and steroidal anti-inflammatory groups. These findings agree with previous information revealing similar efficacy between the pre-emptive use of steroidal and selective COX-2 inhibitor antiinflammatory drugs (10). Within the limits of this study, it may be concluded that the selective COX-2 inhibitor and steroidal anti-inflammatory drugs presented a similar potential for pain and edema relief following periodontal surgery for crown lengthening.

\section{RESUMO}

O objetivo do presente estudo foi comparar a utilização pré-emptiva de medicamento inibidor da COX-2 (cicloxigenase-2) com uma droga antinflamatória esteroidal amplamente utilizada, para o controle da dor e edema após cirurgia periodontal para aumento de coroa. Trinta pacientes que necessitavam de cirurgia periodontal foram aleatoriamente designados a receber uma das seguintes medicações: inibidor seletivo da COX-2 ou a droga antinflamatória esteroidal, $60 \mathrm{~min}$ antes do procedimento cirúrgico. Para avaliar a ansiedade do paciente, a escala de ansiedade ao tratamento dental de Corah foi aplicada antes da cirurgia. Com a utilização de escala analógica visual a extensão de dor/desconforto durante o período trans-cirúrgico e imediatamente após a cirurgia foi mensurada. Adicionalmente, a intensidade de dor/desconforto e edema foram avaliados no periodo pós-operatório tardio 4, 8, 12 e $24 \mathrm{~h}$ após o procedimento cirúrgico. Com relação à ansiedade, não foi observada diferença estatística entre os grupos ( $p>0,05)$. Com relação à extensão de dor/desconforto durante os períodos trans-cirúrgico e pós operatório imediato e tardio, os dados não demonstraram diferenças entre o grupo que recebeu o inibidor seletivo da COX-2 e o aintinflamatório esteroidal ( $p>0,05)$. A avaliação do edema, intragrupo, não revelou diferença estatística durante as primeiras $24 \mathrm{~h}$ em nenhum dos grupos estudados ( $>0,05)$. Em conclusão, ambas as drogas antiinflamatórias utilizadas apresentaram um potencial similar no controle da dor e edema após cirurgia periodontal.

\section{REFERENCES}

1. Pontoriero R, Carnevale G. Surgical crown lengthening: a 12 -month clinical wound healing study. J Periodontol 2001;72:841-848.

2. Deas DE, Moritz AJ, McDonnell HT, Powell CA, Mealey BL. Osseous surgery for crown lengthening: a 6-month clinical study. J Periodontol 2004;75:1288-1294.

3. Vogel RI, Gross JI. The effects of nonsteroidal anti-inflammatory analgesics on pain after periodontal surgery. J Am Dent Assoc 1984;109:731-734.

4. Silva RCL, Riera R, Saconato H. Lumiracoxib for acute postoperative dental pain: a systematic review of randomized clinical trials. São Paulo Med J 2011;129:335-345.

5. Piecuch JF. What strategies are helpful in the operative management of third molars? J Oral Maxillofac Surg 2012;70:s25-s32.

6. Qi DS, May LG, Zimmerman B, Peng P, Atillasoy E, Brown JD, et al.. A randomized, double-blind, placebo-controlled study of acetaminophen $1000 \mathrm{mg}$ versus acetaminophen $650 \mathrm{mg}$ for the treatment of postsurgical dental pain. Clin Ther 2012;34:22472258.

7. Pilatti GL, André dos Santos F, Bianchi A, Cavassim R, Tozetto $\mathrm{CW}$. The use of celecoxib and dexamethasone for the prevention and control of postoperative pain after periodontal surgery. $\mathrm{J}$ Periodontol 2006;77:1809-1814.

8. Laureano-Filho JR, Maurette PE, Allais M, Cotinho M, Fernandes C. Clinical comparative study of the effectiveness of two dosages of dexamethasone to control postoperative swelling, trismus and pain after the surgical extraction of mandibular impacted third molars. Med Oral Patol Oral Cir Bucal 2008;13:129-132.

9. Moore PA, Hersh EV. Celecoxib and rofecoxib: the role of COX-2 inhibitors in dental practice. J Am Dent Assoc 2001;132:451-456.

10. Emery P. Considerations for nonsteroidal anti-inflammatory drug therapy: benefits. Scand J Rheumatol Suppl 1996;105:5-9.

11. Esser RE, Miserendino-Molteni R, Sharr M, Zhang X, Porter W, Ramos L, et al.. Pharmacodynamic behaviour of the selective cyclooxygenase-2 inhibitor lumiracoxib in the lipopolysaccharidestimulated rat air pouch model. Eur J Pharm Sci 2005;25:25-30.

12. López Carriches C, Martínez González JM, Donado Rodríguez M. The use of methylprednisolone versus diclofenac in the treatment of inflammation and trismus after surgical removal of lower third molars. Med Oral Patol Oral Cir Bucal 2006;1:440-445.

13. Ainamo J, Bay I. Problems and proposals for recording gingivitis and plaque. Int Dent J 1975;25:229-235. 
14. Muhlemann HR, Son S. Gingival sulcus bleeding-a leading symptom in initial gingivitis. Helv Odontol Acta 1971;15:107-113.

15. Corah NL. Development of a dental anxiety scale. J Dent Res 1969;48:596.

16. Savage MG, Henry MA. Preoperative nonsteroidal antiinflammatory agents: review of the literature. Oral Surg Oral Med Oral Pathol Oral Radiol Endod 2004;98:146-152.

17. Vogel RI, Desjardins PJ, Major KVO. Comparison of presurgical and immediate postsurgical ibuprofen on postoperative periodontal pain. J Periodontol 1992;63:914-918.

18. Desjardins PJ, Shu VS, Recker DP, Verburg KM, Woolf CJ. A single preoperative oral dose of valdecoxib, a new cyclooxygenase-2 specific inhibitor, relieves post-oral surgery or bunionectomy pain. Anesthesiology 2002;97:565-573.

19. Esen E, Tasar F, Akhan O. Determination of the anti-inflammatory effects of methylprednisolone on the sequelae of third molar surgery. J Oral Maxillofac Surg 1999;57:1201-1206.

20. Philstrom BL, Hargreaves KM, Bouwsma OJ, Myers WR, Goodale MB, Doyle MJ. Pain after periodontal scaling and root planing. J Am Dent Assoc 1999;130:801-807.

21. Ribeiro FV, Nociti-Junior FH, Sallum EA, Casati MZ. Use of enamel matrix protein derivative with minimally invasive surgical approach in intra-bony periodontal defects: clinical an patientcentered outcomes. Braz Dent J 2010;21:60-67.

22. Curtis JW Jr, McLain JB, Hutchinson RA. The incidence of complications and pain following periodontal surgery. $\mathrm{J}$ Periodontol 1985;56:597-601.

23. Zelenakas K, Fricke JR Jr, Jayawardene S, Kellstein D. Analgesic efficacy of single oral doses of lumiracoxib and ibuprofen in patients with postoperative dental pain. Int $\mathrm{J}$ Clin Pract 2004;58:251-256.

24. MacDonald TM, Richard D, Lheritier K, Krammer G. The effects of lumiracoxib $100 \mathrm{mg}$ once daily vs. ibuprofen $600 \mathrm{mg}$ three times daily on the blood pressure profiles of hypertensive osteoarthritis patients taking different classes of antihypertensive agents. Int J Clin Pract 2010;64:746-755.

Received September 16, 2011 Accepted November 26, 2012 